litical scientists should study the nature of authority and, with Ted Gurr, a majesterial (although largely ignored so far) work implementing the idea: Patterns of Authority (Wiley, 1975).

His authority research resulted in a number of essays on political culture, including "A Culturist Theory of Political Change" (APSR, 1988), and social science as a "cultural science." In 1998, he edited and contributed chapters to Can Democracy Take Root in Post-Soviet Russia?

(Rowman and Littlefield), and published an article in Comparative Political Studies on the nature and scope of comparative politics.

Harry Eckstein began his teaching career in the government department at Harvard where he served as an instructor and an assistant professor (1954-58). He moved to Princeton in 1959 as an associate professor and was named the IBM Professor of International Studies in 1969. In 1980, he moved to the School of Social Sciences at the UCIrvine, where he was UCI's first Distinguished Professor.

Professor Eckstein continued to be an active scholar and colleague until the eve of his death. He was an energetic participant in university life at Irvine, where he served as founding chair of the department of politics and society, helped to establish the UCI Center for the Study of Democracy in 1995, and organized many of the Center's activities in recent years. Barely a week before he passed away, Eckstein completed teaching his last course, on political culture. His loss will be felt by the many graduate students he was still supervising, the undergraduates with whom he met regularly in his office, and by his many colleagues at Irvine and around the world who relied on him for wisdom and counsel.

Harry Eckstein was a fellow of the American Academy of Arts and Sciences (1970-99), fellow of the Center for Advanced Study in the Behavioral Sciences at Stanford (195859), Guggenheim fellow (1974), American Political Science Association Annual Meeting program chair (1966-67), APSA vice president (1981-82), editor (1960-63) and member of the editorial board of
World Politics (1960-80), a founding member of the editorial board of Comparative Political Studies (196699), the IBM Professor of International Studies at Princeton University (1969-80), and, finally, Distinguished Professor (1980-93) and Distinguished Research Professor (1993-99) of Political Science at UC-Irvine.

Many of Professor Eckstein's writings are standards of political science and required reading for students. In 1992, a number of his important articles were compiled and published as Regarding Politics (University of California Press). He wrote and edited nine other books. In August 1998, Comparative Political Studies published "A Tribute to Harry Eckstein." No other American political scientist has been honored by a political science journal in this way.

Harry Eckstein was a passionate, serious man. He loved music deeply and played the violin and viola nearly all of his life, often in string quartets made up of friends and colleagues. He followed international soccer and cricket avidly. In recent years, he could be found surfing the net to keep abreast of recent friendlies and test matches. He was an excellent poker player, a game that he mastered in the Army, and he won far more than he lost. Eckstein's conversation, perhaps the most endearing feature of his personality, was always serious and erudite. He seemed to be interested in, and to know an astonishing amount about, any topic that might be raised. He was a deeply committed scholar and a true gentleman who treated all members of the community, from the most accomplished of scholars to struggling undergraduates and members of the staff, with kindness, sincerity, and courtesy.

William R. Schonfield University of California, Irvine Alec Stone Sweet University of California, Irvine

\section{Daniel J. Elazar}

Daniel Judah Elazar, 65, beloved teacher and pioneering scholar, and internationally renowned student of federalism, passed away on Decem- ber 2, 1999, at his home in Jerusalem. Friends are planning a memorial at the 2000 APSA meeting.

In August, Dan had been diagnosed with lymphoma in Philadelphia after directing a summer institute on American constitutionalism for international scholars in Colorado under the auspices of the U.S. Information Agency. Being in the Mountain West was always a joy for Dan. The majestic Rockies symbolized for him both the strengths of America and the challenges of what he saw as America's continuing frontier experience. He returned to Jerusalem to be with his family and in the city that lay at the heart of his work and spirit. Jerusalem and the Rockies very much defined the poles of Dan's own "geohistorical location," a term he developed during his studies of America's cities of the prairie, while Philadelphia, birthplace of the Declaration of Independence and the United States Constitution, symbolized the fertile ground of liberty Americans had come to cultivate between those poles. Dan was immensely sentimental about such matters, and he was a man for whom such symbols were real and important.

Dan is survived by his wife, Harriet; three children, Naomi, Yonatan, and Gideon; three grandchildren; and his brother, David. Dan's principal institutional legacies include the Center for the Study of Federalism and Center for Jewish Community Studies at Temple University, Philadelphia; the Jerusalem Center for Public Affairs in Israel; the International Association of Centers for Federal Studies, of which he was the founding president; and Publius: The Journal of Federalism and Jewish Political Studies Review. Among other activities, he served as a council member and as secretary of the American Political Science Association, chairman of the Israel Political Science Association, a citizen member of the U.S. Advisory Commission on Intergovernmental Relations for three terms, a member of many consultative bodies for the government of Israel, and as an advisor or consultant for the U.S. Senate Subcommittee on Intergovernmental Relations, Education 
Commission of the States, National Governors' Association, Council of State Governments, Israel Mayors Forum, city of Jerusalem, the Jewish Agency, the World Zionist Organization, and most major Jewish organizations in Australia, Canada, South Africa, Western Europe, and the United States.

A prolific scholar and insightful thinker, Daniel Elazar had, at the time of his death, authored, coauthored, or edited 81 books, and had published some 147 academic articles, 201 chapters in books, and 534 other monographs, magazine and newspaper articles, reviews, and the like. Many of his works also were translated into other languages or republished in later years. Among other awards, he received the Distinguished Scholar Award from the Section on Intergovernmental Administration and Management of the American Society for Public Administration (1980), the Outstanding Scholar Award (1993) and Outstanding Book Award (1995) from APSA's Organized Section on Federalism and Intergovernmental Relations, the National Jewish Book Award in 1991, and the Marshall Sklare Award (1994) from the Association for the Social Scientific Study of Jewry. He was twice awarded Guggenheim fellowships and received other fellowships, as well as many grants. Dan had an especially long-term relationship with the Earhart Foundation, which supported his Center for the Study of Federalism. He was a member of Phi Beta Kappa (1957) and also received honorary doctorates of Hebrew Letters from Hebrew Union College-Jewish Institute of Religion (1981) and from Gratz College, Philadelphia (1993).

Dan was born in Minneapolis, Minnesota, on August 25, 1934, a city and state to which he was intensely loyal and which, to him, exemplified many of the best characteristics of American political life and culture, especially what he termed America's moralistic political subculture. His most recent book, which appeared at the time of his death, is Minnesota Politics and Government, coauthored with Virginia Gray and Wyman Spano and pub- lished as part of a series of books he started on "The Governments and Politics of the American States." He received his M.A. (1957) and Ph.D. (1959) from the University of Chicago, where he was especially influenced by Morton Grodzins and Leo Strauss. After Grodzins' death, Dan edited and published Grodzins' The American System: A New View of Government in the United States (1966).

Dan's life, work, and thinking were influenced by the culture of the Midwest, by the American frontier, and by his Sephardic roots. He admired and deeply appreciated the American political experiment and its openness to Jewish life and ideas. He also made an early commitment to Jewish community life in the United States and in Israel. His first two publications were in the Detroit Jewish News (1953), and he served as head librarian for the United Schools Library in Detroit (195159), where he and his brother invented a system for cataloguing Judaica. They later coauthored $A$ Classification System for Libraries of Judaica (1968). For Dan, both Israel and North America were New Worlds for Jews in contrast to the Old World of the past millennium.

After serving as an assistant professor at the University of Illinois (1959-63) and at the University of Minnesota (1963-64), he joined the department of political science at Temple University, his U.S. academic base for the rest of his life. There, he established the Center for the Study of Federalism in 1967 and Publius: The Journal of Federalism in 1970. Three years later, he established the Jerusalem Center for Public Affairs. In 1973, he became professor of political studies at Bar-Ilan University and then chairman of the department for several years (197579). In 1975, he was appointed Senator Norman M. Paterson Professor of Intergovernmental Relations at Bar-Ilan. He also headed Bar-Ilan's Institute of Local Government (1973-99). During the first half of 1999, he served as Distinguished Visiting Professor in the department of religion at Florida International University.

I first met Dan in 1965, when I was serendipitously enrolled in his undergraduate honors seminar, an exciting two-year intellectual and educational odyssey for all ten of us in his seminar. On the first day of class, he had no syllabus to distribute. Instead, he held up William Bluhm's Theories of the Political System and announced: "This will be our textbook for the next two years." Pausing while amazement at such a light reading load registered on our faces, he then said, "In order to discuss the thinkers and ideas presented in this book intelligently, I will expect you to read every article and every book listed in Bluhm's footnotes and bibliography. I will ask you to read a few other things along the way, too." Our amazement turned to astonishment, but our endurance was rewarded richly.

Dan frequently invited us to his home in Wynnefield where discussions continued late into the night and where Harriet, his wife, often delighted in repartee with Dan and with us, and especially in bursting some of his more fantastical intellectual bubbles floated for credulous undergraduates. "Stand up to him," she once admonished us. "He just looks smart, but he's not really that smart." Dan would usually respond with a stern "Harriet!" They were a loving couple who asserted their own identities in ways essential to what Dan regarded as a true covenantal relationship.

Dan's playful soul was perhaps less prominent than his professional persona, but having, for example, seized a water pistol from one of us, he would bring it to class periodically and squirt someone, announcing: "I will squirt Gary every time one of you cannot answer a question, gives the wrong answer to a question, or says something beneath our intelligence." During our last seminar session, he unscrewed the top of his cane, pulled out a vial, and saluted our upcoming graduation by downing the liquid. It was a fitting end to an intense, yet warm and relaxed, two-year Socratic experience with a great teacher and mentor who, despite his prodigious work and crowded schedule, was always available for conversation and advice. Indeed, Dan's delight in unhur- 
ried conversation, playful puns, and both clever and dumb jokes, characterized his life-long relations with everyone.

Dan's work reflects the thinking of a wide-ranging and free-spirited intellect that was more interested in making inventive connections between seemingly disparate phenomena and ideas, in getting to the core of things, and in achieving insight into the human condition than in conforming to the canons of a particular discipline. When asked what he regarded as the ends of social science, he responded simply with "Insight."

Dan was, therefore, relatively unconcerned about traditional academic conventions. Nor did he separate the life of the mind from the life of the world. His scholarly life involved continual engagement with the world and its peoples. As an astute observer, even the most mundane transactions yielded for Dan insights into culture and politics. $\mathrm{He}$ was, in that sense, always working yet, at the same time, not working. Asked if he had any hobbies, he said, "No, I have too many more interesting things to do with my time."

Dan especially delighted in organizing seminars and conferences to discuss and debate ideas, particularly small seminars of 15-20 people that allow in-depth discussion and disallow formal paper presentations. He organized hundreds of meetings, including 24 Liberty Fund seminars, on a myriad of subjects-from liberty in the ancient Near East to covenant theologians of the sixteenth century, writings of the American founders, state constitutions, urban economic development, and novels about the American West-and he participated in many more meetings organized by others. He thrived on the dialogue that lay at the center of his approach to political science. With colleagues Ellis Katz, Donald S. Lutz, Joseph R. Marbach, Stephen L. Schechter, and myself, he also organized several summer institutes for high-school teachers funded by the National Endowment for the Humanities. Education, especially civic education, was a life-long concern for Dan.
He valued constant interaction with political actors too, whether as a scholar interviewing them or as a consultant or advisor working with them. These interactions were, for Dan, important sources of political insight and understanding that grounded his work in practical realities. While he produced highly theoretical work, some quite elegant, it never suffered from arid abstraction or convoluted other-worldliness.

"How can we understand politics if we don't talk to politicians, even to elected dogcatchers, and to regular citizens rather than just to each other?" he argued. In turn, his work was often understood and sought after by political actors.

He also organized institutions, journals, and newsletters to promote research, dialogue, and intellectual exchanges. He was, for example, one of the founders of APSA's Organized Section on Federalism and Intergovernmental Relations, one of the first Organized Sections. He was, in this respect, an entrepreneur, but that term fails to describe his principal objective of trying to create ongoing institutions able to foster scholarly work and engagements with political life on matters supremely important to him. Dan thought in historical generational terms and had a keen sense of each generation's responsibility for future generations.

This responsibility included a duty for social scientists to try to make at least a modest, helpful difference in the world. He especially sought to bring his concepts of federalism and covenant to bear on real conflictsintergovernmental issues in the United States, conflict between Arabs and Jews in the Middle East, the ending of apartheid in South Africa, the hostile bifurcation of Greek and Turkish Cyprus, and the destruction of dictatorships.

As a result, Dan was constantly generating theories, throwing out ideas, and moving across a wide range of intellectual concerns in innovative ways that sometimes drew criticism for not being sufficiently rigorous or empirical methodologically. Yet, while not dismissive, he was largely unconcerned about these matters. He was driven more by the excitement of ideas and dialogue about them. Whether or not one agreed with Dan, his ideas and theories were invariably fresh, challenging, insightful, and original. As a thinker of the first order, he was a model for many students and colleagues.

Dan's first book, The American Partnership: Intergovernmental $\mathrm{Co}$ operation in the Nineteenth-Century United States (1962), was based on his dissertation, which won APSA's Leonard D. White Award for best dissertation in public administration in 1959. This book challenged the notion that dual federalism had prevailed during the nineteenth century by demonstrating considerable practical intergovernmental cooperation during that era. The book provoked controversy, in part, perhaps, because it weakened the novelty of the era of cooperative federalism said to have been ushered in by the New Deal. Dan argued that the New Deal had vastly increased the velocity of intergovernmental cooperation and, indeed, brought the term "intergovernmental relations" into common usage, but it had taken off from a political tradition of intergovernmental cooperation that had been masked by the excessive focus of scholars on the constitutional conceptions of dualistic federalism often put forth by the U.S. Supreme Court.

Dan sought to move the study of federalism into the broader realm of social science and scientific theory rather than leaving it consigned to the realm of constitutional law, which, while critically important, is not the sum and substance of federalism. At the same time, he challenged the contemporary propensity to reduce the study of federalism to intergovernmental relations and public administration. Likewise, he sought to rescue federalism from the view that it is merely an institutional structure that, in the final analysis, is relatively inconsequential. These were all, for Dan, brands of "federalism lite" that lacked the theoretic body and robust flavor of the federalism that flowed from the founders' handiwork and, ultimately, from the Bible, as well as from the character of American politics. 
This book set the stage for themes that would reoccur throughout Dan's work. The concept of partnership was central to his understanding of federalism and to his views on the successes of American federalism. For Dan, a viable federal arrangement requires, fundamentally, voluntary cooperation even while the life of a federal polity is necessarily marked also by conflict, competition, collusion, and coercion. His first federalism reader, coedited with R. Bruce Carroll, A. Lester Levine, and Douglas St. Angelo, was titled Cooperation and Conflict (1969). A system based on dualism alone could not have survived in the first place, in his view, and, indeed, required change, including judicial abandonment of dualism, to focus the federal system on the consequences of the urban-industrial frontier. By the 1980s, though, Dan, like a number of students of American federalism, became concerned about trends toward regulatory coercion and the tendency in both Washington, DC, and academe to define cooperation as the willingness of state and local governments to do the federal government's bidding.

This concern was already somewhat evident in the title of his most well-known book, American Federalism: A View from the States (1966), which, with its 1974 and 1984 editions, was long a staple for students of American federalism. The book was surprisingly successful, given its publication during the height of the Civil Rights Movement when federalism was being identified with racism and reactionary states' rights. Here, Dan also presented his theory of American political subculturesindividualistic, moralistic, and traditionalistic - based on ethnoreligious streams of settlement and patterns of economic activity throughout the United States. The theory generated a large body of empirical research, much of it wholly or partly confirmatory. (See, also, The Ecology of American Political Culture, edited with Joseph Zikmund II in 1975.) During his last days, he was at work on a project with Terry Nichols Clark boldly titled "Political Cultures of the World."

Theories of political culture re- flected another recurring theme in Dan's work: historical continuity in the face of even revolutionary change. Dan was impressed by the ways in which cultures and systems of thought can embrace and tame change, so much so that critics accused him of underrating or overlooking discontinuities. He argued and sought to demonstrate, for example, the presence of many basic continuities in American federalism and intergovernmental relations before and after the Civil War. History, in Dan's view, moved glacially, and he argued that the surface appearances of contemporary political life could not be understood adequately, or their future consequences projected reasonably accurately, without digging down into the layers of geohistorical sediment that form the foundations of the present. Likewise, he argued that genuine foundings of new modes and orders of decent human life-whether the founding of ancient Israel, the founding of the United States, or the founding of a small city on the prairie-have lasting import and impact.

This long view of political history and current events is one reason why, despite his 1934-99 life span and enormous body of work on Jewish affairs, Dan had little to say about the Holocaust. As he wrote with Manfred Gerstenfeld in the November 1, 1999 issue of his Jerusalem Letter/Viewpoints, "While the Holocaust is generally considered one of the key events to understanding world history in the past one hundred years, the same is true-though it is hardly recognized as such-of the Jewish people's finding ways to bounce back." It was the bouncing back, the ability of Judaism and other viable religious, cultural, and intellectual systems to emerge from catastrophe "both damaged and strengthened," that occupied Dan's attention and drove his long-run optimism about life. Moses had again, as in past millennia, prevailed over despicable dregs of human cruelty. (Dan was also fascinated, given his interest in federalism, that it was U.S. state insurance and banking commissioners and attorneys general who forced onto the international agenda the issue of stolen Jewish assets during the Holocaust.)

This long view, coupled with his interactions with political actors, also helped Dan to remain sober but not cynical about politics. He could certainly be critical of particular political actors and political decisions, but he was not disdainful, nor did he believe that he was superior to the objects of his study. Although generally conservative in orientation, he embraced and celebrated pluralism, which was one of the appeals of federalism for him, and he kept partisan leanings at bay in his work.

In Exploring Federalism (1987), another major work, Dan articulated the full theoretical and historical range of his understanding of federalism worldwide. Here, he first fully presented his theory of the covenantal foundations of modern federalism. For Dan, federalism was an overarching political principle that defines political justice, organizes political power equitably, shapes political behavior, informs civil society, and directs humans toward a civic synthesis of power and justice. $\mathrm{He}$ saw federalism as becoming increasingly important in the postmodern world, which he hoped could move away from the old modern reliance on statism. He was especially heartened by the growing international interest in federalism that followed the fall of the Berlin Wall in 1989.

Many of the themes and theories that animated Dan's social science are brought together, applied, and well-articulated in his path-breaking Cities of the Prairie: The Metropolitan Frontier and American Politics (1970) followed by his short case study, The Politics of Belleville (1971). Dan followed these books with longitudinal studies first published with colleagues Rozann Rothman, Stephen L. Schechter, Maren Allan Stein, and Joseph Zikmund II as Cities of the Prairie Revisited: The Closing of the Metropolitan Frontier (1986). A third, follow-up volume is forthcoming, thus constituting a unique longterm study of an important set of American cities from World War II to the 1990 s.

Dan's view of cities and urban life in the United States was at variance 
with much of what has prevailed in urban studies, as reflected, for instance, in his 1966 article, "Are We a Nation of Cities?" which was published in The Public Interest. Dan focused more on the fact that the predominant form of urban settlement in the United States has been the small and medium-sized city, not the big cities that occupy so much academic attention. He was, therefore, an early observer of suburbanization as well, though never critical of it in the manner of so many social scientists. Likewise, while recognizing the problems created by a multiplicity of governments in metropolitan areas, he did not advocate metropolitan governmental consolidation or even formal federal structures for metropolitan areas; instead, he argued that public policy should support and foster the civil community responses to metropolitanization already evident on the prairie and elsewhere.

One of Dan's earlier imaginative and fascinating essays is "Urbanism and Federalism in the United States," published in hearings before the Joint Economic Committee of the U.S. Congress in 1967. There, he argued that one key to understanding urban life in the United States is that Americans patterned their cities more after their conceptions of biblical models with their agrarian elements than after their experiences with European models of "citified" urban life surrounded by peasants; consequently, successful prescriptions for urban ills would have to resonate with Americans' distinctive notions of city life.

Dan's work on Jewish political studies and community life was also prodigious. His Community and Polity: The Organizational Dynamics of American Jewry (1976), often referred to as the "Bible of Jewish communal service," quickly became a classic and was reissued in a revised version in 1995 by the Jewish Publication Society. Rabbi Michael A. Monson, as publisher and executive vice president of JPS, joked with Dan, saying that he had had the privilege of publishing two Bibles: God's and Dan's. Dan also took the Hebrew Bible seriously as a political scientist, not only as an in- fluence on early modern Western political thought and on the American founding but also as a work of political theory in its own right. $\mathrm{He}$ sought to uncover parts of this theory in his 1980 monograph, The Book of Joshua as a Political Classic: A Commentary. Dan also argued, controversially, that Jews have a continuous political tradition that extends back to biblical days, that a people can have polity without a state, and that Jews, in fact, have a portable polity-the Edah.

Dan would probably regard as his culminating synthetic work four recent volumes published under the general title "The Covenant Tradition in Politics": Covenant \& Polity in Biblical Israel: Biblical Foundations and Jewish Expressions (1995); Covenant and Commonwealth: From Christian Separation Through the Protestant Reformation (1996); Covenant \& Constitutionalism: The Great Frontier and the Matrix of Federal Democracy (1998); and Covenant and Civil Society: The Constitutional Matrix of Modern Democracy (1998). Here, he traced the history and permutations of the covenant idea from the Bible to today, seeing as especially important the revival of the covenant idea through the covenant or federal theology of Reformed Protestantism in the sixteenth century. Again, there is an emphasis on continuity of an ancient idea throughout revolutionary change and, for Dan, on the fundamentals of federalism; namely, chesed (covenantal love) and arevut (interdependence and mutual responsibility) among the b'nai berit (partners to the covenant or federal union).

One cannot reflect on Dan's life without also remarking upon his remarkable ability to render his physical disability irrelevant to the extraordinary vigor of his mind, vitality of his soul, and endurance of energy. Having contracted polio as an adolescent, he lived with its gradually debilitating effects, walking with a cane during his younger years, then with two canes, and then needing a wheelchair constantly for mobility. Deciding to purchase his own wheelchair was the only time I ever detected a note of defeat in his voice.
Traveling with Dan, and he traveled virtually everywhere in the world many times, was an eye-opening experience-often traversing a restaurant or hotel kitchen to reach a dining table or meeting room, entering buildings at the rear or through a cargo area, riding freight elevators, soothing an embarrassed host who had organized an event at a place inaccessible for Dan, learning too late that what facility managers defined as "handicapped accessible" was not always accessible for Dan, and negotiating for nearly two hours with authorities at a Brazilian airport until they mobilized a huge cargo lift to remove Dan from his aircraft. Yet, one could also see that legislation can make a difference; access became easier and more widely available by the 1990 s, especially in North America, at a time, moreover, when Dan needed easier access.

When asked by Neal Riemer of Drew University, "What accounts for your immensely productive career?" Dan answered, "I rest on Shabbat." It is to be wished that he were resting only for the seventh day, but the fruits of his life and work offer enduring sustenance. May Daniel J. Elazar's memory in eternal rest, therefore, be for a blessing. John Kincaid Lafayette College

\section{Daniel Elazar: A Reflection}

In the realm of scholarship, Daniel Elazar is one of those individuals who will always remain with us even after he ceased to be a mortal being. I know that I shall never again share the long discussions with Dan, which we had wherever we might meet at many places in this world. What remains with me is the way that I as a political scientist have come to think about the constitution of order in human societies and what it means to become selfgoverning in democratic societies. Dan will always be a part of how those thoughts have come to have meaning for me and others.

As one who had begun to ponder the meaning of federalism viewed from the bottom up, it was my good fortune to have been invited to join 